established in 1983 to promote regional economic co-operation and to establish a Central African Common Market. There are plans for a free trade zone to be established.

Members. Angola, Burundi, Cameroon, Central African Republic, Chad, Democratic Republic of the Congo, Republic of the Congo, Equatorial Guinea, Gabon, São Tomé e Príncipe.

Headquarters: BP 2112, Libreville, Gabon.

Website: http://www.ceeac-eccas.org

President: Joseph Kabila (Democratic Republic of the Congo).

Secretary General: Louis Sylvain-Goma (Republic of the Congo).

\section{Economic Community of West African States (ECOWAS)}

Founded in 1975 as a regional common market, and now planning to introduce a single currency, the eco, before the end of 2009, ECOWAS later also became a political forum involved in the promotion of a democratic environment and the pursuit of fundamental human rights. In July 1993 it revised its treaty to assume responsibility for the regulation of regional armed conflicts, acknowledging the inextricable link between development and peace and security. Thus it now has a new role in conflict management and prevention through its Mediation and Security Council, which monitors the moratorium on the export, import and manufacture of light weapons and ammunition. However, it still retains a military arm, ECOMOG. It is also involved in the war against drug abuse and illicit drug trafficking. Members. Benin, Burkina Faso, Cape Verde, Côte d'Ivoire, The Gambia, Ghana, Guinea, Guinea-Bissau, Liberia, Mali, Niger, Nigeria, Senegal, Sierra Leone, Togo.

Organization. It meets at yearly summits which rotate in the different capitals of member states. The institution is governed by the Council of Ministers, and has a secretariat in Abuja which is run by an Executive Secretary.

Official languages: English, French, Portuguese.

Headquarters: 101 Yakubu Gowon Crescent, Asokoro, Abuja, Nigeria.

Website: http://www.ecowas.int

Email: info@ecowas.int

Executive Secretary: Dr Mohamed Ibn Chambas (Ghana).

\section{Intergovernmental Authority on Development}

The Intergovernmental Authority on Development was created on 21 March 1996 and has its origins in the Intergovernmental Authority on Drought and Development, which had been established in 1986. It has three priority areas of co-operation: conflict prevention, management and humanitarian affairs; infrastructure development; food security and environment protection.

Members. Djibouti, Ethiopia, Kenya, Somalia, Sudan, Uganda. Eritrea was formerly a member but withdrew in April 2007.

Headquarters: PO Box 2653, Djibouti, Republic of Djibouti. Website: http://www.igad.org

Executive Secretary: Mahboub Maalim (Kenya).

\section{Lake Chad Basin Commission}

Established by a Convention and Statute signed on 22 May 1964 by Cameroon, Chad, Niger and Nigeria, and later by the Central African Republic, to regulate and control utilization of the water and other natural resources in the Basin (Sudan has also been admitted as an observer); to initiate, promote and co-ordinate natural resources development projects and research within the Basin area; and to examine complaints and promote settlement of disputes, with a view to promoting regional co-operation.

In Dec. 1977, at Enugu in Nigeria, the 3rd summit of heads of state of the commission signed the protocol for the Harmonization of the Regulations Relating to Fauna and Flora in member countries, and adopted plans for the multi-donor approach towards major integrated development for the conventional basin. An international campaign to save Lake Chad following a report on the environmental degradation of the conventional basin was launched by heads of state at the 8th summit of the Commission in Abuja in March 1994. The 10th summit, held in N'Djaména in 2000, saw agreement on a US\$1m. inter-basin water transfer project.

The Commission operates an annual budget of $1 \mathrm{bn}$. francs $\mathrm{CFA}$, and receives assistance from various international and donor agencies including the FAO, and UN Development and Environment Programmes.

Official languages: English, French.

Headquarters: BP 727, N’Djaména, Chad.

Executive Secretary: Engr. Muhammad Sani Adamu.

\section{Niger Basin Authority}

As a result of a special meeting of the Niger River Commission (established in 1964), to discuss the revitalizing and restructuring of the organization to improve its efficiency, the Niger Basin Authority was established in 1980. Its responsibilities cover the harmonization and co-ordination of national development policies; the formulation of the general development policy of the Basin; the elaboration and implementation of an integrated development plan of the Basin; the initiation and monitoring of an orderly and rational regional policy for the utilization of the waters of the Niger River; the design and conduct of studies, researches and surveys; the formulation of plans, the construction, exploitation and maintenance of structure, and the elaboration of projects.

Members. Benin, Burkina Faso, Cameroon, Chad, Côte d'Ivoire, Guinea, Mali, Niger, Nigeria.

Official languages: English, French.

Headquarters: BP 729, Niamey, Niger.

Website: http://www.abn.ne

Executive Secretary: Muhammad Bello Tuga (Nigeria).

\section{Southern African Customs Union (SACU)}

Established by the Customs Union Convention between the British Colony of Cape of Good Hope and the Orange Free State Boer Republic in 1889, the Southern African Customs Union was extended in 1910 to include the then Union of South Africa and British High Commission Territories in Africa and remained unchanged after these countries gained independence. South 